\title{
[I]羊毛之合成緎維
}

編上羊毛とは昔から資重交維維として人問に愛されて

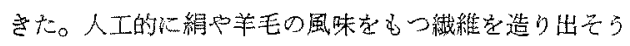
とする人間の夢は，今世紀の初頃から実を結びはじめ，

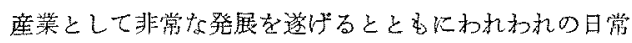

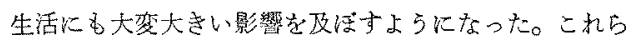

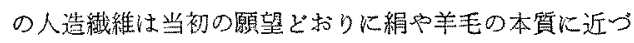

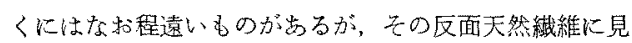
られない美点をる多く具文被服溨維として独立的地歩を 確立するに至った。しかし近年合成蟣維を中心として人

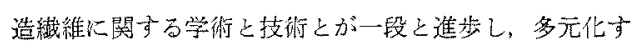

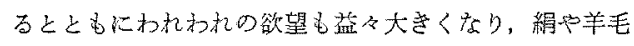

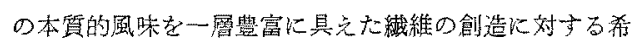

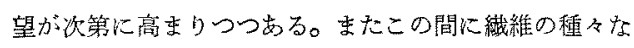
性貿を支配する分子構造户超分子構造の研究が准歩し, われわれの希望を実現させる手段も次第化蚞く学術的 基碮の上に立つようになってきた。

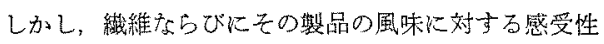

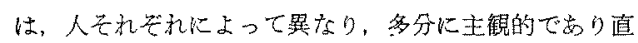
感的である。促って例充ば“ウーリイタッジという語

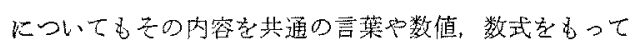

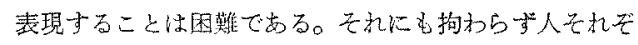
れ特有の感觉をもって羊毛の特微を知得し，他の織維に 勝る蛙力を感している。IWS(国際羊毛事務局)はこれを —“羊毛に代る羊毛はなし”—“There is no substitute for wool”——表現している。

䄉維の特性を表示するための物理的拉よび化学的特性 は極名て多数にのぼっている。その数值のすへてを羊毛 のそ礼占等しくすることは不可能であるが仮りに主

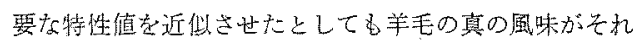
から生れ出るとは限らない。しかし特性随儿基つくこの

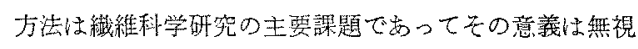
されてはならない。

一万瀻維を桡成する分子の構造，形態および集合状熊

\section{Wool and Synthetic Fibers}

MASAO HORIO

京都大学名賞教授 緎維学会前会長

\section{堀尾正雄}

などから䄉維の性質を予知することも重要な手段であ る。例完ば“シルキィタッチ”を具現さ坊る目的で最近

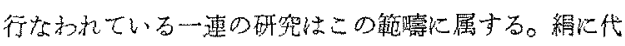
るものとして 66 ナイロンが生れた。このもの怯主鎖代 アミド結合をもっている点では綟と類似であるが，メ レン基の含有量が多いので蝢状の触感を与えヤング率も 小さい。そこで分子鎖中のメテレン基の数の少ないポり アミド（例完ば 3 ナイロンあるいは 4 ナイロン等）を造 れば綟により近い触感が生れるであ万らと期待される。 また剻珄せグメントとしてシクロへキサン環を分子鎖中

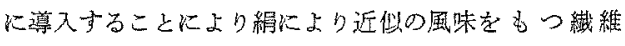
(Qiana)をつくる一逨の研究舟着々実行汇移されてい ঔ。

羊毛様瀻維の慗造を上記のよらな化学的配虑のるとに 設計することは現段階に挍いては不可能に近い。羊毛が たん白から粠成されていることに着目して，カゼイン，

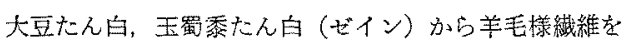
つくる研究が大変盛んに行なわれた時代がある。しかし そのいずれ㒵成功しなかった。これは羊毛らラチンの本

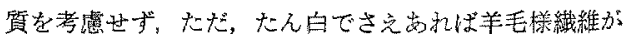
生れるであららといら荒磨無敕な帰納基づくものと思 われる。もち諭，失敗の原因性他に多々多った。一 方，期待されなかった結果から偶然に産業の発展をむた ら寸例す屡々見受けら机る。アクリル瀻維は化学棈造に

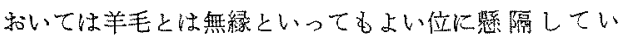
る。亦た超分子構造も非常に相墥している。关机飞も拘

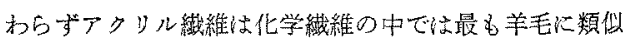
の特性をもつとい和羊毛の市場に大き進出乙てい る。アクリル㵶維の中の何ものがウーリィタッ千の源を なすのであるらか。

羊毛ケラチンは 18 種類のアミノ酸からできているが， その組合せと順序とはいまだ十分代解明导九ていない。 この点では比較的少数のアミノ酸からなる綃フィブロイ ンに比べて非常に複雑である。絹系の生成は，すべての 化学瀻維製造の場合之同粎化，“紡系啵”を“紡采”する ことによって行なかれる。從って超分子棈造も化学䋐維 
Vol. 2, No. 11 (1969)

のそれと共通点をもっているから，これを解明すること は比較的容易である。これに反して羊毛纎維の “発生” は全く異なる機構によって行なわれ生成物の構造も極め て複雑である。従ってヶラチンの化学に立朋して羊毛様 轹雓の彆造を志すことは現段階では不可能に近い。

しかし、ここに全く別のアプローチがある。私は羊毛 に関するわれわれの最初の論文の冒頭において，「羊毛 の被服織維としての高い位置はその細かくて安定な捲縮 に依存する」と記した。若しも羊毛が真直ぐで挍縮をも たなかったならぱ，他に如何なる美点があろらとも，そ れらのすべては水泡に帰するであろら。羊毛製品のふく よかな, 弾力に充ちた温い感触は安定で纎細な捲縮に負 ら所が大きい。ここにおいては繊維を满成する物質の種 類ならびに熱的性質は単に二次的意義をもつに過ぎな い。従って物質素材それ自身よりも，まず形態とそれに 関連する諎性質を羊毛に近似させることが，ウーリィタ ッチを具現させる重要な要素と考只られる。羊毛が持つ 細かくて安定な捲縮に関しては, 以前に故小原亀太郎博 士によって発見され，近土教授と私達が体系づけたバイ ラテラル棈造に負うことが明らかにされた。ここにいう ハイラテラル系とは, 力学的挙動を異にする 2 つのセグ メントからなる系を指し，本質的には蕒巻（つるまき） ばねのようにコイルをつくる性質をもつ。羊毛では $2 つ$ のセグメントを染色性, 膨潤, 紫外線吸収, 耐薬品性等 の差によって識別することができる。第1図は染色法で 明示されたメリノ羊毛の横断面のバイラテラル構造を示 す。

パイラテラル系は物質の如何をとわない。従って合成 維維においてもこれを具現させることができる。最初に 市販されたパイラテラル合成瀻維はデュポン社の Orlon Seyelleであろう。これは各単瀻維が性質を異にする 2 成分からできているアクリル繊維で羊毛样の掍縮を具え ている。バイラテラル構造の応用はアクリル繊維だけに 限ら次い。ナイヌン, ポリエステル, ポリオレフィン等 およそすべての台成緎維の分野に利用され，ウーリィ夕 ッチと羊毛樣弾力の具現に広く貢献している。

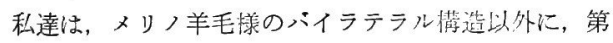
2 図のよ5に2 成分が偏心欈造をもつタイプの緎維の製 造を発表したが，聞くところによればこれも最近米国で 大きい関心をひいているといら。このように，物質の種 類を超越し, より普遍的な組織に着目し羊毛の特質を具 現する万法は今後子益々発展するであるら。

人工的にパイラテラル構造をつくる研究と工業とは益 々発展しつつある。しかし，神秘的でいまだ解き難い謎 は, 羊毛が如何なる機構によってパイラテラル構造をつ くるかといら点である。これを解明するためには毛が毛

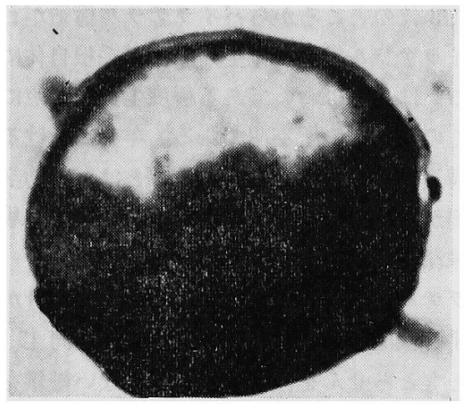

第 1 図 メリノ羊毛の横断面

pH 7 にて Methylene Blue にて染色したもの 白い部分 $A$-cortex (para-cortex), 染っている部分 B-cortex (ortho-cortex)

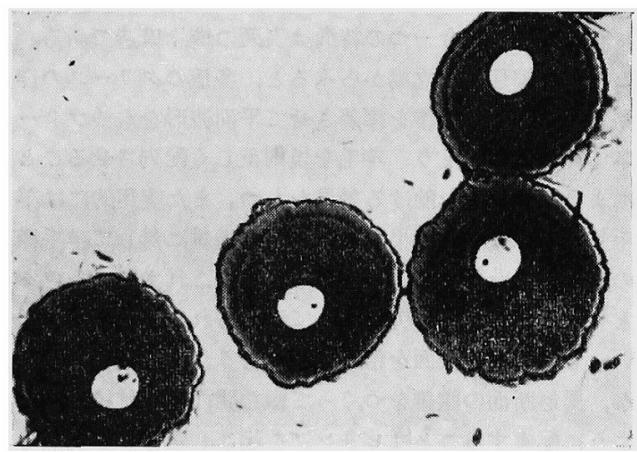

第 2 図偏心型コンジュゲート䋐維の横断面 （黒く見光る部分は 6 ナイロン，内部の白く見壳る部分 はポリエチレンテレフタレート)

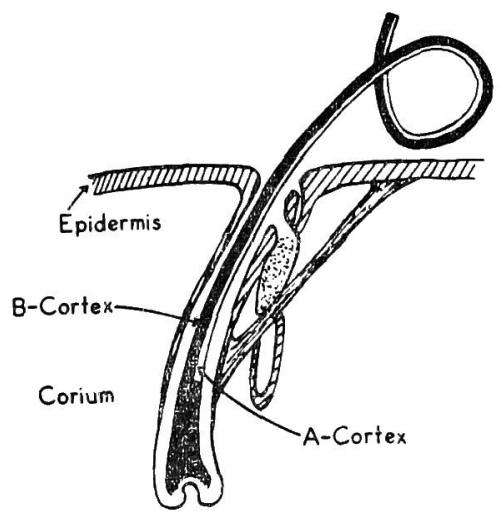

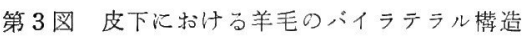

根から発生し生長して行く過程学研究しなけ机ばなら い。いまパイラテラル構造を作る 2 つのセグメントを染 色法によって識別すると，第 3 図に示したように，羊毛 が毛根から発生して表皮に達与るまでの皮下に和ける長 
さの約 $1 / 3$ 位のところからパイラテラルル满造が目撃され る。パイラテラル構造の発生の原因が毛根自体に在るの

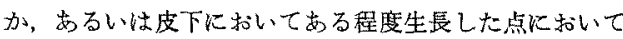
発生するのか目下の所不明である。羊毛に和忛るパイラ テラル棈造発生の機構を解明することは，動物学，発生 学的立場からみても，織維科学および工業的立場からみ ても興味深くまた重要な事柄である。

バイラテル構造をもつ合成瀻維は，厹れ自身がらせん を形成する機能を具劣ている点で羊毛と同じである が，为ともとらせんを作る性能をむたない瀻維を人工的 に稩かいループに卷きそ机を加熱してセットするという 素朴な原理を利用したいわ的るウーリィ加工无現在盛え 飞行なわれている。これも羊毛の䄉維形態の利用の 1 例 といらべきであらう。

羊毛の形態の今一つの特改は表面の模片構造で心る。 これは撩縮理論の立場からみると，多量のグリースの作 用之共に，各単繊維を賿着させて平面波形をるつフリー ス (fleece)をつくり、羊毛を規則正しく即列させること により毛の密生を助计る効果をるつ。また実用的化は羊 毛独特のフェルト効果を生さ。化学瀻維に対して羊毛様 の鱗片構造を付与し上らとする研究忙これまで包色々 と行なかれてきたが労多くして酬いられるところが少な い。しかし絨維表面を粗剈化するような加工を行なう か, 異形断面の織維をつくって䬥維間の摩擦抗抗を增す ように配虑することはどリングを起こし難くする利点を 生む。この程度の工夫は赛行性もまりその意義は無視で きないであうう。

羊毛ケテチンの化学棈造は非常に複雑で完全な蕃造決 定は不可能に近い。しかし化学構造関渾した数多の特 徵を挙げることができる。その最も顕着なものはシスキ ンのジサルファイド結合で，個々のシスチン分子が関与 する2本のポリペプチド鎖を横に結合している。またケ ラチン中には，リジン，アルギニンの上う㑥イオン性 の側鎖をるつアミノ酸と，アスパラギン酸，グルタミン 酸の上らに陰イオン性の䚋鎖をるつアミノ酸が存在し， 一つの鎖の陽イオン側鎖の束端上，別の鎖の陰イオン側 敛の末端々がクーロム力の作用圈内比近接するときは， 雨方の鎖恃イオン結合炕よって横汇結ばれる。また羊毛 中にはセりン，スレオニン，チロシン等の水酸基をるり アミ八酸禹可成り多量含まれているが，これらの水酸基 が一定の距離化近接して対峙するとき水素結合をつく りポリペプチド鎖を横に装ぐ。本た水素結合は同一鎖 の中にも生成していリックス構造を安定化するこ之にも 役立つ。いいいずれにしても羊毛ケラチンに拈いては 種頪の異なる架橋が多数存在することが特徵である。羊 毛タラチンか゚他の多くのたん白比へてて熱安定性の高い
ことはこれらの架橋に負ら所が多い。合成高分子におい ても多官能性モノマーを用いて熱硬化性樹脂をつくる以 外酒，熱可塑性澍脂成分炕架橋剂を添加して硬化する か，放射線めるいは化学的手段によって線状ポリマーを 架橋して熱安定性，不溶性，ヤング率等の高い生成物を つくることが盛ん研究されているが，羊毛はそれらの 研究を促がした貴重な手本としての役目を果してきた。

シスチン架橋は羊毛クラチンの最大の特徽の一つであ るが、ジサルファイド結合は化学的に不安定て酸化むる い虫還元反応によって容易に切断する。これが羊毛筫品 の收縮をもたらす原因となっている。一方羊毛ヶラチン は反応性に富む側鎖を多量に含んでいるので人工的炕架 橋する可能性皮非常に多い。最初の試みはSpeakman （1936）によって行なわれた。彼はフォスダンを用いて 羊毛を架橋し安定化することを試みたが，皇れ以来今日 势でこの方面の研究が多数行な斿れている。第 4 図は Rouette (1966) が七パキン酸パラニトロフェニルェス テルを架橋戍としてポリペプチド鎖間化セバチル基を導 入した結果を模型的画いたものである。

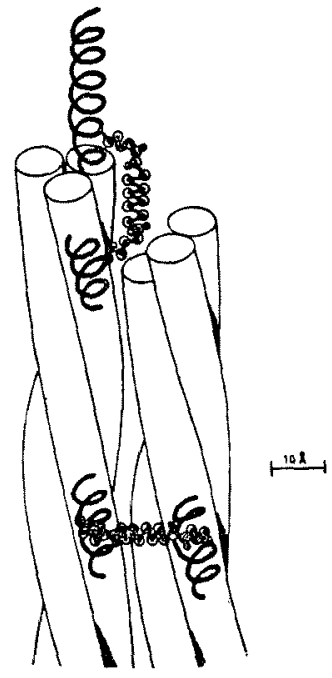

第4図七バチル基沈よる羊毛の架橋の模型図 (H.K. Routte, Melliand Textiberichte, 47, 903 (1966) より引用)

今年 4 月瀻維学会創立 25 周年記念式舆の招待講演者 として来日されたドイッのアーヘン工科大学の Zahn 教 授は，その記念講演 “Crosslinking and Selfcrosslinking Reactions in Wool”, 飞执いてケラチン化学の本質 に触れた非常に興味のある，末発表の新しい多くの事実 を明らかとした。例えば，新しい架橋郕として，p， $p^{\prime}$ difluoro- $m, m^{\prime}$-dinitrodiphenyl sulfone 在羊毛红作用 
させ，生成した架橋を分離すると，sulfone-bis-tyrosine， sulfone-bis-lysine 以外に sulfone-lysine-tyrosine $z^{3}$ 多量に生成することを見出した。すなわち、リジン同志 めるいはチロシン同志が向き合って存在する確率より も、リジンとテロシンが対峙して存在する確率の方が多 いことが明らかとなり，羊毛の構造解明の上に有益な資 料を提供している。また陽イオン性側㒹と陰イオン性側 鎖とからイオン結合を生成することをさきにのべたが， 羊毛を，例穴ば酪酸》ロライドで処理すると，両側鎖が 化学的に反応してアミド結合を生成し新しく主原子価架 橋を形成することを胃出している。そして、リジンとグ

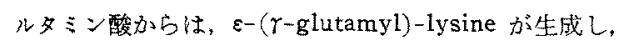

また，リジンとアスパラギン酸から， 8 -( $\beta$-aspartyl)lysine が生成することを立証している。これらを定量 することにより，リジン、グルタミン酸招よびアスパラ ギン酸等羊毛タラチン中の重要成分の配疽に対して大き い手がかりが充られ，タラチンの構造決定の上に非常に 役直D。

熱硬化性樹脂はいらに及ばず，架橋された高分子は一 般に酎熱性は高いが力学的には硬くて脆い。それに比べ ると羊毛は架樀の程度が高いにも拘わらず極めて柔軟性 に富み，杜力・ひずみ曲線では総ての絬織轼維の中で最 も平坦な形状を示している。かつて Astbury (1941)は

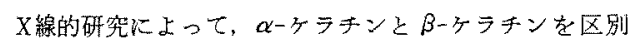

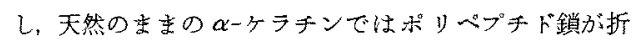
り畳まれた形状を示し、これ方羊毛瀻維に高度の延伸性

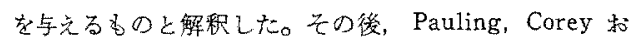

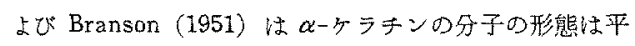
面状の折り賹又ではなくて, 特定の立体的らせん形をと ることを明らかにし，この研究を前駆として一般化され た $\alpha$ ーヘックス理論を体系化することに成功した。 $\alpha-$ ヘリッタス代関するこれら一連の研究は，その後判明し た立体規則性ビ二ル化合物のーリカル構造と相俟って高 分子構造の新しい分野を開拓したが，その陲機となった アラチンに関する研究は高分子化学の進步の上にも非常 に意義深いるのといか柅ばならない。

合成ポリペプチド，例えば， poly ( $($-benzyl-L-glutamate), poly (L-glutamic acid) 等はいわ方 helicogenic solvent の中では溶液中に私いても スの形態をとっている。羊毛の場合 18 個のアミノ酸が 不明の順度で結合してポりペブチドをつくっている。杂 ずケラチン分子中のシスチン架橋を切断し，次にペプチ ド鎖沉沿って分子を適当な大童さに酵素分解し，それを クの切片中のアミノ酸の種類と順序とを決定するととも に, helicogenic solvent 内に拉ける形態を穓察するこ とにより，ヶラチン尔子中の如何なるアミノ酸順位がへ
リックス構造に笴与するかを究明することがでるるであ ろら。目下稚垣教授等によってこの方面の研究が進めら れている。もしこの研究が成果を学げるならばポりペプ

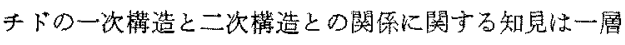
進歩するであるら。

\section{むす ず}

羊毛は紡織轼維として他の追徒を許さない多くの美点 をもっている。その生因のすべてを明らかにすることは 不可能で焉る。しかし羊毛が保有する瀻細で安定な捲縮 は羊毛に特異の感螌を与文る重要な要素の一つである。 メリノ、コリデール羊毛の安定な捲縮はぐイラテラル構 造に起因与る。パイラテラル構造が㨡縮を発生する理論 は物質素材に関係なく普遍的に成立する。従って合成瀻 維の分野に和いてもこの原理を灾用して，現在多種多様 のパイラテラル棈造をるついわるコンジュダート綪維 が，羊毛様感触とらくよか子弾力を禹製品をつくる目 的で工業的に生産されている。

羊毛ケラチンの化学棈造は極めて複雑でその全貌を明 らかにすることは不可能に近い。しかし分子中には主原 子価怙よび副原子価からたる架橋が極的て多数存在して

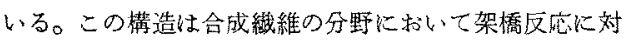
する興味を呼び起こした。るラチン分子中のシスチン架 橋は酸化，還元反応を受け易くその結果容易に分裂す る。また種々な試薬に対しても銧敏でるる。こでシス チンの架橋に代って安定な架橋を新しく分子内に設置す る試みが 1936 年以降盛んに行なわれるよらになり、こ

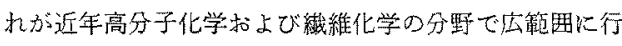
な放れている架楿泪の研究の前駆をなした。

架橋剂の導入によってケラチン分子内に設置される橋 および自己架橋反応に上って生成する橋を分離し，定量 することにより特定のアミノ酸の分布に効して新しい知 見が得られ，羊毛テラチンの構造沠定のための一助とな りつつある。

羊毛ゲテン中にはーリックス成分が多量含まれてい ることが確喼されたが、これが基礎となって天然蛙よび

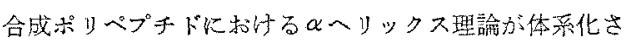
れ高分子科学の発展儿蕃しく寄与した。

羊毛ケラチンは 18 種類のアミノ酸からできているが 分子中におけるアミノ酸の配置执よび順位は十分に解明

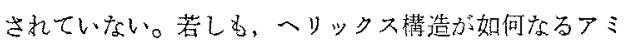
ノ酸順位に基づくかが解明され，さらにアミノ酸の配置 について現在以上に深、知見が得られたならば高分子化 学の発展の上代寄与するところが非常に大きいである $5 。$ 